\title{
Learning Evaluation of Mathematics during the Pandemic Period COVID-19 in Jakarta
}

\author{
Rizal Kamsurya ${ }^{1 *}$ (1) \\ ${ }^{1}$ Sekolah Tinggi Keguruan dan Ilmu Pendidikan Media Nusantara Citra, INDONESIA \\ *Corresponding Author: rizal_kamsurya@stkipmnc.ac.id \\ Citation: Kamsurya, R. (2020). Learning Evaluation of Mathematics during the Pandemic Period COVID-19 in Jakarta. International Journal \\ of Pedagogical Development and Lifelong Learning, 1(2), ep2008. https://doi.org/10.30935/ijpdll/8439
}

\begin{abstract}
This research aims to evaluate the learning of mathematics at the college level conducted through distance learning programs during the COVID-19 pandemic in Jakarta. This research is a type of evaluation research using the Context, Input, Process, and Product (CIPP) model that is (1) context consists of program background and program planning (2) Inputs include of students readiness, teaching materials, facilities and infrastructures (3) process consisting of teaching methods and constraints in learning, and (4) the product consists of understanding and learning outcomes. Respondents in this study amounted to 155 students spread across five colleges in Jakarta. The instruments used for data collection are unstructured questionnaires and interviews. The validity of the device used is expert judgment. Furthermore, data is analyzed in a descriptive and interpretation to obtain an accurate picture of factual conditions in the field. The results showed that the mathematical learning conducted through distance learning at higher education in Jakarta needs improvement and improvement in quality from various aspects such as preparation, facilities and infrastructure, material materials, and learning methods used in the effort to achieve the objectives of the established differentiation. It based on the evaluation result on the context component; Score value 3.325 with outstanding category, input component; Score 2.86 by good category, process components; Score 2.80 by good grade, and product component; Score 2.26 with the less good group.
\end{abstract}

Keywords: evaluation, Mathematics learning, COVID-19

Received: 21 May 2020 Accepted: 15 Jul. 2020

\section{INTRODUCTION}

The spread of the Corona Virus (COVID-19) has occurred in almost all countries, including in Indonesia. World Health Agency has even established the spread of this virus into a world pandemic because of its rapid and massive range. Pandemic COVID-19 affects every sector of life, including health, economics, tourism, and Education (Sintema, 2020). Consequently, all human activity is required from home to break the chain of Coronavirus propagation so as not to expand. DKI Jakarta, as the largest centre for the spreading of Coronavirus in Indonesia, has adopted Work from Home (WFH) since mid 15 March 2020 (circular letter of the Governor of DKI Jakarta, 2020) including learning activities. Any company or educational institution is required to work and carry out learning activities from home by utilizing various media or online-based platforms. It is undoubtedly a challenge for lecturers and students because, during this time, the learning is carried out directly through face-in, more specifically in mathematics learning.

Mathematics as a Queen of Science (Ramdani, 2006) is essential to be owned by everyone as a basis in developing the mindset and problem-solving. Therefore, mathematics should be using appropriate strategies and methods so that students can have a good understanding of ability and able to apply in daily life. Existence of Pandemic COVID-
19, lecturers, must be able to design or plan to learn well so that the objectives of the learning has achieved to the fullest. Similarly, students should be able to adapt to the learning pattern without going through face-to-face.

Problems that arise as a result of the above conditions are when the whole college is obliged to perform the learning during the pandemic COVID-19. Still, the lecturers are not prepared to design learning appropriately for distance learning, including making teaching materials that correspond to distance learning. Also, the platform used cannot facilitate learning activities interactively. Borisova et al., (2016) revealed that distance learning could run effectively and efficiently if elearning platforms to facilitate learning activities, the use of precise and innovative learning methods, and specific training conducted. As a result of the above conditions, mathematics learning only lasts according to the capacity and ability of the lecturer. Will undoubtedly impact the quality of the understanding gained by students, as mathematics learning requires intensive interaction between lecturers and students. The results showed that pandemic COVID-19 had an impact on the quality of education in Zambia due to the lack of communication between students and teachers not facilitated by elearning (Sintema, 2020). 
Based on the above problems, it is necessary to take an appropriate evaluation of the distance learning program applied by higher education in Jakarta to determine its effectiveness and achievement. One of the right evaluation models is used to determine the success rate of mathematics learning through distance learning, using the evaluation of Context, Input, Process, and Product (CIPP) model. CIPP Model is a strategic and precise evaluation form to improve the quality of education programs (Shang in Darma, 2019). The CIPP model has a complete stage and comprehensive so it can evaluate the performance of each program dimension by using specific criteria as an effort to improve the quality of the program used. The result of this evaluation expected to be the basis of consideration for higher education to improve and innovate learning by utilizing technology to achieve learning objectives.

\section{METHODOLOGY}

This research is a type of evaluation research using the CIPP model developed by (Stufflebeam, 2003) with four stages; (1) The context consists of the program background and the planning of distance learning programs (2) inputs comprised of students ' readiness, materials/materials, facilities and infrastructures (3) process consist of teaching methods and problems/constraints in learning, and (4) the product consists of understanding teaching materials and motivation learning.

\section{Sample Size}

Respondents in this study amounted to 155 students spread across 5 colleges in Jakarta. Sample selection is made using the purposive sampling technique, which is the determination of the sample using certain criteria (Sugiono, 2014). The criteria used are students of the Mathematics Education Study program that originated from the universities in Jakarta as well as the learning methods used during the COVID-19 pandemic using distance learning.

\section{Data Collection}

Data collection is done online using Microsoft Form and interview by phone. This technique is done because of the limitations of researchers and respondents to do face-to-face directly. The form of instruments used for data collection are polls and unstructured interviews. Surveys shared through Microsoft Form are distributed to social media as well as WhatsApp group students with a time period of the respondents' study for 3 weeks. Interviews were conducted to obtain accurate data on the implementation of learning during the COVID-19 pandemic and the social and psychological impacts of students directly. The selection of respondents for interviews by phone is made randomly with the representation of each college in Jakarta. The validity of the instrument used is an expert judgement which is the process of validity testing of the contents of the device by professional or expert (Azwar in Ujiyono, 2018)

\section{Data Analysis}

Data analysis is done in a descriptive sense to obtain a factual depiction of mathematical learning during the COVID-19 pandemic. Data analysis focused on poll results and interview results.
Table 1. Categorizing the implementation of distance learning programs

\begin{tabular}{lclcc}
\hline Variable & Indicators & Score & Category \\
\hline Context & $\bullet$ & Distance learning program background & 3.325 & Very Good \\
& $\bullet$ & Planning distance learning programs & & \\
\hline Input & $\bullet$ & Student Readiness & 2.86 & Good \\
& $\bullet$ & & \\
& $\bullet$ & Teaching materials & & \\
\hline Process & $\bullet$ & Teachilities and infrastructure & 2.80 & Good \\
& $\bullet$ & Constraints in learning & & \\
\hline Product & $\bullet$ & Material understanding & 2.28 & Less Good \\
& $\bullet$ & Learning motivation & & \\
\hline
\end{tabular}

\section{Context Indicator}

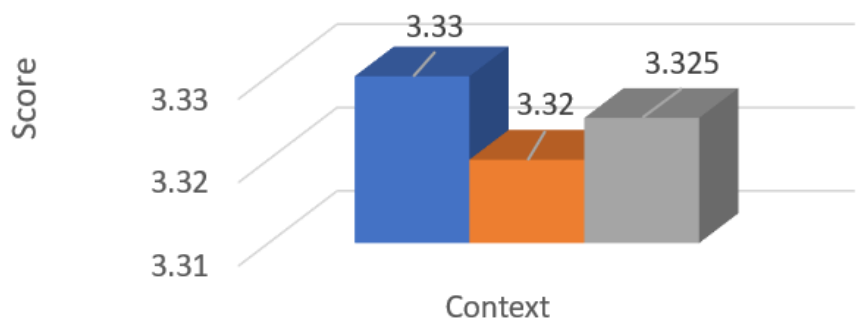

Indicator 1 Indicator $2 \quad$ Average

Figure 1. Context Component Evaluation Results

\section{RESULTS}

The result of the evaluation of mathematics learning during the pandemic COVID-19 at the Jakarta Regional College shown in Table 1.

\section{Context Component Analysis}

There are two indicators analyzed in the context component; (1) background of the distance learning program and (2) planning distance learning program. The results of the analysis are in Figure 1.

Figure 1 shows that the first indicator obtains a score of 3.33 with the category good once, and the second indicator gets a score of 3.32 with a first category, the average context component with a score of 3.325 belongs to the group very good. Shows that the implementation of learning mathematics through distance learning is backed by the current COVID-19 pandemic conditions and well planned by each college through various platforms accessible by lecturers and students.

The long-distance learning performed during the COVID-19 pandemic was an alternative solution for students to conduct social distancing, thereby reducing the risk of contracting the COVID-19 virus. The interviews showed that distance learning was carried out not based on the appropriate curriculum and the Use of uniform learning tools or applications for the entire lecturer. The college does not have sufficient time to adapt or prepare the curriculum with the learning system as well as develop e-learning to suit the needs of students and their respective colleges. Lecturers and students are encouraged to conduct distance learning without being given maximum training in using online media for learning. Consequently, there is a lack of Use in application or e-learning, because lecturers are given the freedom to use familiar forms and according to the needs of learning materials. 


\section{Input Indicator}

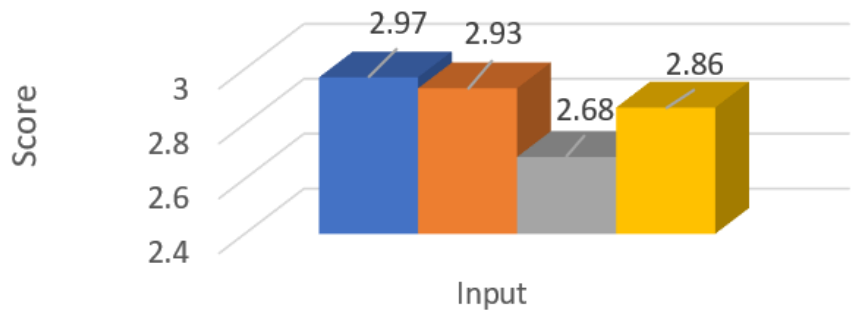

Indicator 1 Indicator 2 Indicator $3 \square$ Average

Figure 2. Input Component Evaluation Results

\section{Input Component Analysis}

Input component evaluation to be able to obtain appropriate and suitable resources for use in mathematics learning (Warju, 2016). Such resources are human resources, infrastructure, time, and content (Aziz et al., 2018). The input components analyzed are (1) Student readiness, (2) teaching materials, and (3) facilities and infrastructure. The results of the analysis of input components presented in Figure 2.

Based on Figure 2, it revealed that the input component evaluation result has a score of 2.86 and belongs to the category good. The achievement of each indicator is that the student readiness indicator earns a score of 2.97 and belongs to the top grade, the teaching material indicator scores the score of 2.93 with the category good, and the means and infrastructure indicators score 2.68 by good category.

The importance of improving the vital input quality is done in mathematics learning, because it can affect the quality of output resulting from the teaching. The results of the input component analysis even though it shows all indicators have a good category, but need to be improved especially on the aspects of facilities and support that have the lowest value score. This is due to distance learning is hugely determined by adequate facilities and infrastructure so that the learning process can take place well. Because, through the facilities and infrastructure, the teaching materials that have been designed by the lecturer will be converted into quality distance learning data (Leontyeva, 2018).

The results of the interview showed that the mathematical learning that took place during the COVID-19 pandemic at higher education in Jakarta used various online platforms or applications, including elearning, google classroom, Edmodo, Ms. Teams depending on the policies of each lecturer and higher education. The use of various platforms or applications aims to facilitate lecturers and students to carry out long-distance learning. But such knowledge is not based on the appropriate curriculum, as it focuses on the curriculum used for face-to-facial education. As a result, distance learning quality does not get optimal results Alipichev et al., (2017) reveals that distance learning can run maximum if supported by the appropriate curriculum so that it can determine the competencies to achieve. It is undoubtedly not only the findings in the research but also the material evaluation to develop an integrated curriculum by utilizing technology as an online learning medium.

\section{Process Component Analysis}

The evaluation process aims to know clearly and provide a complete description of the various activities undertaken in a program (Stuffelbeam in Aziz et al., 2018). Besides, through this evaluation,

\section{Process Indicator}

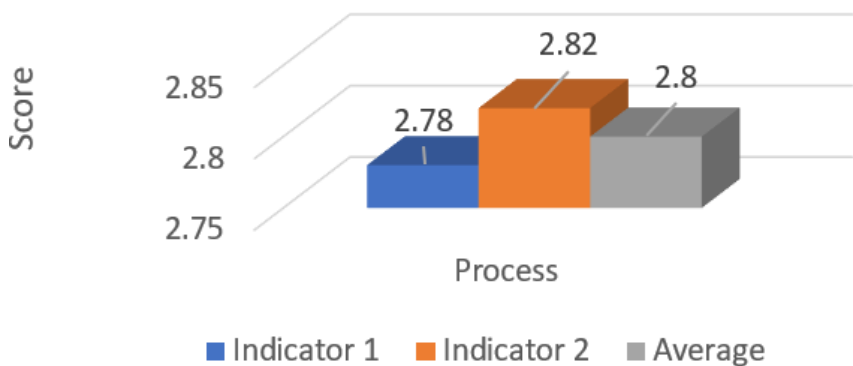

Figure 3. Process Component Evaluation Results

various shortcomings and failures in the process of implementing an application can be known (Junanto, 2019). There are two indicators analyzed at the process stage; (1) learning methods and (2) constraints acquired during learning-the results of the process analysis of learning mathematics conducted through distance learning done in Figure 3.

Based on the analysis results in Figure 3, it is known that the average score obtained by the process component is 2.8 with a good category. The average rating of the first indicator is 2.78 with a suitable type, and the second indicator scores the 2.82 value with a good grade.

The results above show that the process component of the distance learning program belongs to the category good, but a variety of fixes and improvements are required. Learning objectives can be achieved if the teacher can use the appropriate method in the learning process (Afandi et al., 2013). Based on the interviews, there are several findings related to the implementation of distance learning in the COVID-19 pandemic that needs improvement and improved quality of application, among others; (1) Colleges in DKI Jakarta have no specialized curriculum for emergency conditions, including at the time of pandemic COVID-19. This resulted in the learning of mathematics carried out through distance learning while still focusing on the currently used curriculum. Consequently, there are some objectives not achieved, because in the study students have to go to the field (school), the use of specific applications that are only biased accessed through the campus server or learn in groups; (2) Lecturers and students are not prepared optimally to conduct lectures through distance learning. There is no specialized training for lecturers to develop materials that suit the needs of students while attending conferences through distance learning programs. Consequently, lecturers only perform lectures (arranging lecture materials) by the skills owned; (3) Lecturers must use more than one application or platform in the speech because no application or platform can facilitate complete course activities. Lecturers use E-learning, Edmodo, or Google classroom to upload course materials, discussion topics and assignments, and video conferencing through the Zoom app to explain the content. The use of Video conferencing is only performed on particular courses and materials, as students feel overwhelmed by the increasing needs of internet quota. This must be a matter of consideration and need to be sought for the solution, so that mathematics learning can be active through distance learning and can achieve the objectives of the teaching that has been established; (4) The discussion process does not take place effectively when lectures performed. The student considers the discussion to be an activity to answer questions not as a container to find solutions to problems. Student inactivity in the discussion process also affects the achievement of this activity. Therefore, lecturers must 


\section{Product Indicator}

ㅎํㄴ

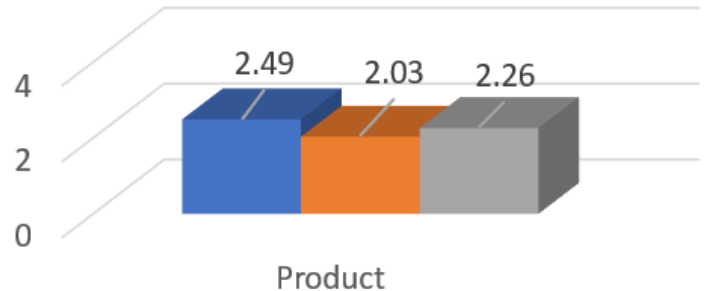

- Indicator 1 - Indicator $2 \square$ Average

Figure 4. Product Component Evaluation Results

find the right method or strategy to develop the student's business and change the student's perception of discussion activities; (5) The availability of networks or Internet connections also negatively impacts the process of processing or mathematical learning. Students do not as a whole have a stable Internet connection when they are at home during the COVID-19 pandemic. Consequently, students find it difficult when lecturing, and not all students can do video conferences when scheduled by the lecturer.

\section{Product Component Analysis}

Product component evaluation is done to know the results obtained from the implementation of the program. Through evaluation of product results achieved during lecture or mathematics, learning through distance learning can be measured and interpreted as far as the achievement of implementation of the program (Topno in Lestari et al., 2017). Product Component analysis results presented in Figure 4.

Based on Figure 4, it revealed that the results of the product evaluation have an average score value of 2.26 , with the category less useful. The achievement of each indicator is (1) material understanding has a score of 2.53 with the group less valuable, and (2) learning motivation achieved by students have a score of 2.03 in the category less good. These results indicate that the results of mathematics learning obtained through distance learning programs have not been by the objectives of the teaching that has established. Because the aspect of understanding mathematics material by students also looks low, it needs evaluation and improvement of various elements.

Based on the interviews there are several obstacles experienced by students that impact the level of understanding of materials and learning motivation achieved by students, among others; (1) Mathematics material requires a detailed explanation, and some lecturers do not do a video conference to explain the lecture material. Various aspects are underlying this, including the unlimited number of Internet quotas that the students have, poor internet connection, and material explanation, but not such as learning done through face to face. This problem must undoubtedly be a severe concern from various parties (colleges, lecturers, and students) through a variety of intensive preparation and mentoring programs so that distance learning can run effectively and efficiently; (2) The material provided by the lecturer through the distance learning platform has not been sufficiently studied by the students independently. Consequently, students are hard to understand the content well when learning from home. The material provided is still text or guidebooks without being equipped with material explanations. Therefore, specialized training is required to create and design learning materials to suit the learning programs used;
(3) There is difficulty learning in groups because of the limited ability of students in understanding the lecture materials; (4) Students have not leveraged the available references from various sources to understand the lecture materials well; (5) The low motivation and anxiety to the virus transmission of COVID-19 also affect the student's mindset to strive for a good understanding of lecture materials.

\section{DISCUSSION AND IMPLICATIONS}

The current pandemic COVID-19 requires every college to implement distance learning to avoid the spread of coronaviruses by utilizing technology. This policy is a positive and appropriate response to anticipate the widespread proliferation of viruses as the results of the research conducted by Mulenga \& Marbán (2020) that digital-based learning (online) is a positive response during the school's closing period when pandemic COVID-19. Mobile-based (online) Use of remote learning allows learning to be carried out anytime and anywhere and is an inevitable alternative during the COVID-19 pandemic (Naciri et al., 2020). Distance learning can take place effectively if supported by adequate facilities and infrastructure as well as the use of appropriate learning strategies. Therefore, each college should be able to prepare sufficient and maximal facilities and infrastructures during distance learning implementation.

The results of this study showed that the mathematical learning that took place through distance learning at higher education in Jakarta had not achieved maximum outcomes according to the objectives set in the curriculum. Various aspects are underlying. This is the unavailability of appropriate curriculum, adequate facilities and infrastructure, and the use of less precise methods of learning. This is because the spread of pandemic COVID-19 in Jakarta occurs quickly, and the college does not make maximum preparation to face the current situation. Consequently, the results achieved are not by the objectives set. Various complaints arise from students as a result of this learning, including Internet connection and the many tasks of lecturers who have an impact on their health and psychological condition. While at the same time, everyone required to maintain and enhance the immune system to avoid the spread of coronaviruses. The learning methods used in distance learning need to be improved as an effort to improve the understanding and motivation to learn students including tools and platforms used, such as integrating the Google meet application into elearning (Basilaia \& Kvavadze, 2020)

Therefore, a concrete step is required to solve this problem based on the results of the research obtained. Universities should be able to develop a curriculum that adjusts to emergency conditions so that the competencies that must be achieved by students can be carried out well. The achievement of learning skills by using distance learning (online) should not be confused with face to face Learning (Basilaia \& Kvavadze, 2020). Universities should also prepare facilities and infrastructures that can facilitate lecturers and students to implement learning effectively and efficiently, including the availability of digital library features and features to interact through video conferencing. Lecturers must be facilitated with a variety of abilities and skills, especially in using the right teaching methods and designing interactive teaching materials, to help students to learn mathematics in a structured and comprehensive manner. 


\section{CONCLUSION}

Learning mathematics conducted through distance learning at colleges in Jakarta needs improvement and improvement of the quality of various aspects such as preparation, facilities and infrastructure, material materials, and learning methods used in the effort to achieve the objectives of the prescribed differentiation. It based on the evaluation result on the context component; Score value 3.325 with top category, input component; Score 2.86 by good type, process components; Score 2.80 by good category, and product component; Score 2.26 with the less good group. Thus, the lowest score on the distance learning program is the product component. This is, of course, the maximum improvement and improvement needed to achieve the defined learning objectives.

\section{REFERENCES}

Afandi, M., Chamalah, E., \& Wardani, O. P. (2013). Model Dan Metode Pembelajaran Di Sekolah. In Perpustakaan Nasional Katalog Dalam Terbitan (KDT) (Vol. 392, Issue 2). https://doi.org/10.1007/s00423006-0143-4

Alipichev, A. Y., Khalevina, S. N., Trubcheninova, A. A., \& Fedulova, A. N. (2017). Solutions to foreign language training courses implemented using distance learning tools, 12(1), 59-68.

Aziz, S., Mahmood, M., \& Rehman, Z. (2018). Implementation of CIPP Model for Quality Evaluation at School Level: A Case Study. Journal of Education and Educational Development, 5(1), 189. https://doi.org/10.22555/joeed.v5i1.1553

Basilaia, G., \& Kvavadze, D. (2020). Transition to Online Education in Schools during a SARS-CoV-2 Coronavirus (COVID-19) Pandemic in Georgia. Pedagogical Research, 5(4). https://doi.org/10.29333/pr/7937

Borisova, O. V., Vasbieva, D. G., Malykh, N. I., Vasnev, S. A., \& Bírová, J. (2016). Problem of using innovative teaching methods for distance learning students. Mathematics Education, 11(5), 1175-1184.

Darma, I. K. (2019). The Effectiveness of Teaching Program of CIPP Evaluation Model: Department of Mechanical Engineering, Politeknik Negeri Bali. International Research Journal of Engineering, 5(3), 1-13. https://doi.org/10.21744/irjeis.v5n3.619
Junanto, S. (2019). Evaluation Model of Expertise Practice Programs for Early Childhood Educator Teachers. JPUD - Jurnal Pendidikan Usia Dini, 13(1), 128-142. https://doi.org/10.21009/jpud.131.10

Leontyeva, I. A. (2018). Modern distance learning technologies in higher education: Introduction problems. Eurasia Journal of Mathematics, Science and Technology Education, 14(10), 1-8. https://doi.org/10.29333/ejmste/92284

Lestari, S., Rosana, D., \& Supahar. (2017). The Development of CIPP Evaluation Model Instruments on the Application of Science Project Learning Assessment. 4th ICRIEMS Proceedings, 57-64. http://seminar.uny.ac.id/icriems/sites/seminar.uny.ac.id.icriems/f iles/prosiding2017/SE10_SRI.pdf

Mulenga, E. M., \& Marbán, J. M. (2020). Is-COVID-19-the-Gatewayfor-Digital-Learning-in-Mathematics-Education. Contemporary Educational Technology, 12(2), ep269. https://doi.org/10.30935/ cedtech/7949

Naciri, A., Baba, M. A., Achbani, A., \& Kharbach, A. (2020). MobileLearning-in-Higher-Education-Unavoidable-Alternative-DuringCOVID-19. Aquademia, 4(1), ep20016. https://doi.org/10.29333/ aquademia/8227

Ramdani, Y. (2006). Kajian Pemahaman Matematika Melalui Etika Pemodelan Matematika. Jurnal Sosial Dan Pembangunan, 22(1), 2. https://ejournal.unisba.ac.id/index.php/mimbar/article/view/198

Sintema, E. J. (2020). Effect of COVID-19 on the Performance of Grade 12 Students: Implications for STEM Education. 16(7), 1-6.

Stufflebeam, D. L. (2003). The CIPP Model for Evaluation. International Handbook of Educational Evaluation, 31-62. https://doi.org/ 10.1007/978-94-010-0309-4_4

Sugiono. (2014). Metode Penelitian Pendidikan; Pendekatan Kuantitatif, Kualitatif, dan $R \& D$ (20th ed.). Alfabeta.

Ujiyono, I. (2018). Evaluasi Program Pendampingan Implementasi Kurikulum 2013 Di Kabupaten Wonosobo. Media Manajemen Pendidikan, 1(1), 97. https://doi.org/10.30738/mmp.v1i1.2883

Warju, W. (2016). Educational Program Evaluation using CIPP Model. Innovation of Vocational Technology Education, 12(1), 36-42. https://doi.org/10.17509/invotec.v12i1.4502 